\title{
Quantifying the role of woody debris in providing bioenergetically favorable habitat for juvenile salmon
}

\author{
Andrew W. Hafs ${ }^{\mathrm{a}, \mathrm{d}, *}$, Lee R. Harrison ${ }^{\mathrm{b}}$, Ryan M. Utz ${ }^{\mathrm{c}}$, Thomas Dunne ${ }^{\mathrm{d}}$ \\ a Department of Aquatic Biology, Bemidji State University, Bemidji, MN 56601, USA \\ ${ }^{\mathrm{b}}$ NOAA Fisheries, 110 Shaffer Road, Santa Cruz, CA 95060, USA \\ ' National Ecological Observatory Network, 1685 38th Street, Suite 100, Boulder, CO 80301, USA \\ d Bren School of Environmental Science and Management, University of California, Santa Barbara, CA 93106, USA
}

\section{A R T I C L E I N F O}

\section{Article history:}

Received 29 October 2013

Received in revised form 2 March 2014

Accepted 16 April 2014

\section{Keywords:}

Oncorhynchus tshawytscha

Large woody debris

Bioenergetics

Hydrodynamic modeling

Central Valley

Habitat enhancement

\begin{abstract}
A B S T R A C T
The habitat complexity of a riverine ecosystem influences the bioenergetics of drift feeding fish. We coupled hydrodynamic and bioenergetic models to assess the influence of habitat complexity generated by large woody debris (LWD) on the growth potential of juvenile Chinook salmon (Oncorhynchus tshawytscha) in a river that lacked large wood. Simulations indicated how LWD diversified the flow field, creating pronounced velocity gradients, which enhanced fish feeding and resting activities at the sub-meter scale. Fluid drag created by individual wood structures increased under higher wood loading amounts, leading to a 5-19\% reduction in the reach-averaged velocity. The reach-scale growth potential was asymptotically related to wood loading, suggesting that the river became saturated with LWD and additional loading would produce minimal benefit for the configurations we simulated. In the scenario we analyzed for illustration, LWD additions could quadruple the potential growth area available before that limit was reached for the configurations selected for demonstration. Wood depletion in the world's rivers has been documented extensively, leading to widespread attempts by river managers to reverse this trend by adding wood to simplified aquatic habitats. However, systematic prediction of the effects of wood on fish growth has not been previously accomplished. We offer a quantitative approach for assessing the influence of wood on habitat potential for fish growth at the microhabitat and reach-scales.
\end{abstract}

() 2014 Elsevier B.V. All rights reserved.

\section{Introduction}

The ecological and esthetic characteristics of river channels do not result from the interaction of water and sediment alone. Living and dead vegetation supplied from the riparian zone and the catchment upstream plays a fundamental role in the formation of the river channel and its flow conditions, and thus in the production of bioenergetically favorable habitat for aquatic species (Collins et al., 2012; Gurnell, 2012). The amount and quality of habitat for a given species and life-history stage are widely described and sometimes quantified (Beechie and Sibley, 1997; Harmon et al., 1986). However, we know of no attempt to formally predict the extent and quality of habitat resulting from various levels of wood loading

\footnotetext{
* Corresponding author at: Department of Aquatic Biology, Bemidji State University, Bemidji, MN 56601, USA. Tel.: +1 2187552789.

E-mail addresses: ahafs@bemidjistate.edu (A.W. Hafs), lee.harrison@noaa.gov (L.R. Harrison), rutz@neoninc.org (R.M. Utz), tdunne@bren.ucsb.edu (T. Dunne).
}

in a channel. Such predictions, however, would prove valuable for habitat enhancement and restoration projects.

At any position within a river, the ability of drift-feeding fish to exploit their environment and grow to maturity depends on the availability of low-velocity zones, in which to maintain position, that are close to higher-velocity zones utilized for feeding (Fausch, 1984). Such conditions require that flow fields within stream channels be spatially complex with strong stream-wise and cross-stream velocity gradients. Although the interaction of flow and sediment is capable of producing spatial patterns of habitat favorable for various life stages (Trush et al., 2000), this interaction alone tends to create smooth, stream-lined forms without the strong depth and velocity gradients that supply the recommended flow complexity (Harrison et al., 2011). Exceptions to this generalization occur at the sub-meter scale such as near the beds of boulder-rich streams and at bedrock outcrops (Crowder and Diplas, 2000; Harrison and Keller, 2007). However, the most widespread and effective agent forcing morphological and hydraulic complexity on channel flows in lowland, alluvial rivers is large woody debris 
(Bocchiola, 2011; Gurnell et al., 2005, 2002; Keller and Swanson, 1979).

Simplification of channels through wood removal has been documented throughout North America (Collins et al., 2002; Sedell et al., 1982; Sedell and Froggatt, 1984; Triska, 1984) and many modern restoration projects attempt to reverse the trend. From 1800 to 1950 , most LWD in rivers was removed to improve navigation or scoured out by splash dam operation to transport logs to mills (Sedell et al., 1982). For example, in the Willamette River, Oregon, riparian trees were removed and LWD was pulled from the stream, reducing the spatial density of downed trees in the channel from one every $1.6 \mathrm{~m}$ to one every $300-400 \mathrm{~m}$ (Sedell and Froggatt, 1984). Although LWD substantially influences the physical complexity of rivers and floodplains (Gurnell et al., 2005) and is often installed as part of riverine habitat restoration (Roni and Quinn, 2001), quantified estimates of how much should be added and what benefit to expect are lacking. Applying such estimates could substantially improve understanding of the linkage between reach-scale habitat value and supplies of LWD from the drainage basin (Benda et al., 2003) and the likelihood that restoration efforts positively impact the target species.

Recently developed bioenergetic models allow the prediction of growth rates and the extent of favorable locations for driftfeeding fish in rivers (Booker et al., 2004; Hayes et al., 2007, 2000; Railsback et al., 2013; Rosenfeld and Taylor, 2009). Empirically derived coefficients depicting relationships between swimming speed, temperature and prey intake are used in these models to define growth rates, while drift density and capture efficiency coefficients express energy intake. By coupling a hydrodynamic model of spatial variations in flow depth and velocity with such a bioenergetic model, energy intake, energy use, and growth rate can be integrated for each location in the model domain to compute the net growth potential for a fish during a season with variable flow and food supply. The area of habitat with the potential to support growth to a chosen size within a season can then be mapped. Coupling bioenergetic models with computations of how velocity gradients are generated by various amounts of LWD provides a systematic way of quantifying the effectiveness of natural or engineered wood loading in determining the growth potential of fish in a given habitat. Studies have demonstrated variable benefits for juvenile fish from LWD additions (Cederholm et al., 1997; Everett and Ruiz, 1993; Roni and Quinn, 2001; Shields et al., 2003), but there remains the need to generalize and quantify the ecological links between catchment wood supplies, in-stream wood loads, habitat complexity, and biotic responses.

We coupled hydrodynamic and bioenergetic models of fish growth to calculate the reach-scale extent of bioenergetically favorable rearing habitat for juvenile Chinook salmon (Oncorhynchus tshawytscha), a culturally, recreationally, and commercially important anadromous species in western North America. The coupled model illustrates the roles of water velocity, depth, temperature, invertebrate food supply, and channel form on potential rates of salmon growth, but we held the spatial and temporal patterns of these variables constant in all simulations and explored the result of imposing hydrodynamic complexity on the flow field with varying degrees of wood loading. The longer-term goal of this work is to construct a quantitative theory of the relationships between catchment and riparian conditions determining water flows, channel dimensions, riparian shade, wood loading, in-channel hydrodynamics, and the bioenergetics of fish growth. Such a theory would support quantitative understanding of how straightening of river channels and removal of large woody debris (LWD, >1 m length, $>0.1$ m diameter) from channels throughout much of North America and Europe have contributed to the decline of fish populations (Benda et al., 2003; Floyd et al., 2009; Nelson et al., 2003; Noss et al., 1995; Sada and Vinyard, 2002; Slaney et al., 1996). This theoretical framework would also illustrate the scale and intensity of changes that would be required to mitigate the effects of channel simplification on fish populations.

\section{Materials and methods}

\subsection{Study location and period}

We simulated the addition of varying LWD loading amounts $\left(\mathrm{m}^{2} / 100 \mathrm{~m}\right.$ of river) to a reach of the Merced River, California, USA (latitude $37^{\circ} 29^{\prime} \mathrm{N}$, longitude $120^{\circ} 28^{\prime} \mathrm{W}$ ), the current southernmost river with a native population of Chinook salmon. The Merced River has been impacted by multiple impoundments, gravel mining, water withdrawals, and historic hydraulic mining, resulting in degraded spawning and rearing habitat for Chinook salmon. In the spring of 1997, a river channel avulsion during a flood event redirected all flow to an abandoned gravel mine. Agencies charged with salmon management considered this new channel unsuitable for salmon spawning and rearing and subsequently implemented the Merced River Salmon Habitat Enhancement Project (MRSHEP), an effort that created a new meandering channel meant to evolve into a semi-natural geomorphologic state under the modern discharge and sediment regimes (see Marshall et al., 2008 for a full description of the project). Because of the channel construction activities, paucity of wood from upstream sources, and wood removal for navigation purposes, there has been little local recruitment of woody vegetation to the MRSHEP channel. Lack of woody debris and the simple geometry of the reach provide an opportunity to quantify how adding large wood to the channel would influence the flow field and the area of bioenergetically favorable habitat for juvenile salmonids.

The simulation period, 12 April-30 June ( 80 days), was selected because during this time, juvenile Chinook were known to be present in the reach, invertebrate drift data were available, and discharge was held constant by a dam approximately $10 \mathrm{~km}$ upstream of the study reach. These factors provided a favorable opportunity to model the influence of LWD on fish growth under typically managed conditions. For all simulations the starting fish size was $7 \mathrm{~cm}$ long, which is the approximate average juvenile Chinook length at the simulation start date (Utz et al., 2012). A fish was considered to be viable if it reached $10 \mathrm{~cm}$, a length $\geq$ average out-migrating smolt in the Merced River (Montgomery et al., 2007), by the end of the simulation period. We did not attempt to model the preemergence life-stage, which begins when fall run juvenile Chinook salmon hatch in January (Utz et al., 2012).

Once hatched, Chinook grow within the lowermost $15 \mathrm{~cm}$ of water above the bed, where we have measured and modeled velocities of less than $0.5 \mathrm{~m} / \mathrm{s}$, and in the "interfacial sublayer" (the upper few $\mathrm{cm}$ of the substratum among the protruding gravel particles) where velocities drop to about one-half of their magnitudes at the bed surface (Pellachini, 2011). Thus our model simulations represent the post-emergence period after Chinook are capable of leaving the interfacial gravel sublayer and the lowermost portion of the flow field, utilizing the complex velocity field higher in the water column.

\subsection{Hydrodynamic model}

The flow field was simulated, without bed deformation, with the Flow and Sediment Transport Morphological Evolution of Channels (FaSTMECH) model developed by the U.S. Geological Survey (Barton et al., 2005; Lisle et al., 2000; Nelson et al., 2003). FaSTMECH is a two-dimensional (2D) flow model and assumes a hydrostatic pressure distribution (small vertical velocities and accelerations). Though there are potential non-hydrostatic effects created when 
wood is added to a channel they are likely small and are not included in a 2D model. We do not expect that the spatial pattern of the computed flow field would be changed significantly by using a full 3D flow model and there are reported precedents of successful use of 2D flow models to simulate velocity gradients, transverse flows and flow complexity around obstructions (Crowder and Diplas, 2000; Pasternack et al., 2004). The model, previously calibrated and validated at the field site for a range of discharges (Harrison et al., 2011; Legleiter et al., 2011), computes the local depth and vertically-averaged velocity magnitude. True model validation of the LWD scenarios is not possible, though model results are comparable because we used an identical approach between simulations in terms of how wood was added and we used the same hydraulic boundary conditions (discharge, flow resistance and downstream stage). In that aspect, our approach shares similarities with previous work testing various restoration designs through alteration of the input topography (DEM), which in turn is used as input into 2D hydraulic models (Pasternack et al., 2004; Wheaton et al., 2004). The cell size used in the computations was $0.5 \mathrm{~m} \times 0.5 \mathrm{~m}$, which closely matched the expected maximum capture distance (Hughes and Dill, 1990) of juvenile Chinook salmon in our simulations.

We first used FaSTMECH to simulate the flow field without any woody structure in the channel, representing the current conditions. To simulate the addition of woody debris, we created flow-obstructions fully penetrating the water depth, that were $0.7 \mathrm{~m}$ wide (the diagonal width of a flow cell) and $5 \mathrm{~m}$ or $10 \mathrm{~m}$ long, protruding into the channel in a downstream direction at an angle of $45^{\circ}$ to the bank and placed on alternating sides of the channel. The selected width was representative of the LWD pieces in nearby reaches of the river (Utz et al., 2012), and Stella et al. (2006) reported mean tree diameters of $0.77 \mathrm{~m}$ for mature cottonwood in the nearby Tuolumne River, CA. The lengths of 5 and $10 \mathrm{~m}$ were similar to those reported by Senter and Pasternack (2011), who found average wood lengths of $6.9 \pm 4.0 \mathrm{~m}$ on the Mokelumne River, CA. Natural wood pieces are oriented at a range of angles and in complex log jams, but we selected a $45^{\circ}$ angle and uniform spacing for simplicity; extra diversity could be accommodated by the models in future simulations. Initial flow simulations indicated that the structures created wake lengths (the downstream flow recirculation zone created by the added structures) of approximately 30 and $40 \mathrm{~m}$ for 5 and $10 \mathrm{~m}$ structures, respectively. A total of 10 simulations were conducted for each structure size (5 or $10 \mathrm{~m}$ ) with wood spacing varying systematically between 2.0 and 0.2 wake lengths. For examples of output datasets from the FaSTMECH see Supplement 2. The FaSTMECH model can be downloaded at: http://i-ric.org/en/introduction.

\subsection{Bioenergetic model}

The bioenergetic model was based on a drift feeding model developed and tested by Rosenfeld and Taylor (2009). Estimated growth of a fish residing in a $0.5 \mathrm{~m} \times 0.5 \mathrm{~m}$ cell was calculated as a function of energy consumed minus energy lost through swimming costs, excretion, egestion, and specific dynamic action (Beamish, 1974). A fish was positioned in one cell and the velocity in that cell was used to determine the energy lost due to swimming costs, inclusive of basal metabolism (Hughes and Dill, 1990; Rosenfeld and Taylor, 2009). The fish could feed from adjacent cells within the maximum possible prey capture distance (Hughes and Dill, 1990) of the fish. The adjacent cell with the fastest water velocity was used to determine the supply rate of the prey. This strategy likely resulted in a slight overestimation of energy intake at all locations but should not influence the ability to make relative comparisons of growth potential benefit between different wood loadings. By including swimming costs and allowing fish to feed from adjacent locations, the drift feeding model reflects the laboratory based conceptual model of Fausch (1984) where profit is optimized by combining slow water near strong velocity gradients to balance swimming cost expenditures against food supply.

The cross-sectional area of the river that the fish could feed from (based on the local flow depth and the maximum capture distance for a given prey size) was then multiplied by the drift velocity and drift concentration to estimate the food supply in any time period. Net energy intake was calculated by multiplying food supply and the probability of capture success. Capture success (ranging from 0-1) was a function of water depth at the fish location, drift velocity, fish fork length, and prey length (Hill and Grossman, 1993; Hughes and Dill, 1990). Similar to Sommer et al. (2001), Madenjian et al. (2004) and Koehler et al. (2006), all parameter values used in the bioenergetic model were taken from the Fish Bioenergetics 3.0 (Hanson et al., 1997). Drift concentrations (mean $=0.4 \mathrm{mg} / \mathrm{m}^{3}$ dry mass during the simulation period) were derived from eight drift samples collected within the study reach between 12 April and 21 June, 2008. Juvenile Chinook salmon in the reach feed primarily on Baetis and Hydropsyche (Utz et al., 2012), so maximum capture distances and drift concentrations were based on these two prey. Once net energy intake was calculated, energy was converted to mass each day, based on the energy density of the fish, and added to or subtracted from initial fish weight to determine growth.

Mean daily water temperature $\left(14.3^{\circ} \mathrm{C}\right.$ average during simulation period) was obtained from the closest available California Department of Water Resources gauging station (22.6 km downstream of the study reach on the Merced River). For all simulations, discharge was held constant at $6.4 \mathrm{~m}^{3} / \mathrm{s}$, the level normally maintained in the reach through controlled dam releases during the simulation period when juvenile salmon are present in the reach (Utz et al., 2012). For additional bioenergetics model details and source code, see Appendix A and Supplement 1, respectively.

\subsection{Combining models to quantify growth-positive habitat}

The predicted depths and velocities for every cell in the reach derived from the FaSTMECH model were applied in the bioenergetic model to compute the potential fish growth rate over the 80-day simulation period. Maps were then calculated for each LWD loading amount estimating the extent of positive juvenile salmon growth and areal estimates of habitat that allow a fish to grow from the initial fish length of $7 \mathrm{~cm}$ (average size of fish present in the reach on 12 April; (Utz et al., 2012)) to at least $10 \mathrm{~cm}$ long. We also analyzed how river channel morphology influenced the potential growth area by comparing the bioenergetically favorable growth areas in curved and straight sections of the channel. To assess the relationship between velocity differential and growth rate, we made a series of scatterplots that compared velocity differential to growth rate for cells with similar depths.

The relationships between LWD loading amounts and the areal estimates of favorable juvenile salmonid habitat produced were described by regression equations developed using nonlinear regression techniques from package nls2 (Grothendieck, 2010) in program R (R Core Team, 2012). Regression equations summarizing the model results were then used to estimate potential growth area created if the woody debris loading amount was equal to the values measured for 20 California rivers with Chinook salmon populations (Albertson et al., 2013). We also estimated the potential growth area created when wood loading amount was equal to that for unmanaged or lightly managed rivers in regions similar to the Central Valley of California. Gurnell et al. (2002) provided an average loading amount of $55 \mathrm{t} /$ ha for such rivers; Senter and Pasternack (2011) measured 9.2t/ha in the nearby Mokelumne River. We multiplied the ratio of these values by an areal estimate of wood loading $\left(11 \mathrm{~m}^{2} / 100 \mathrm{~m}\right)$ from Senter and Pasternack (2011) 


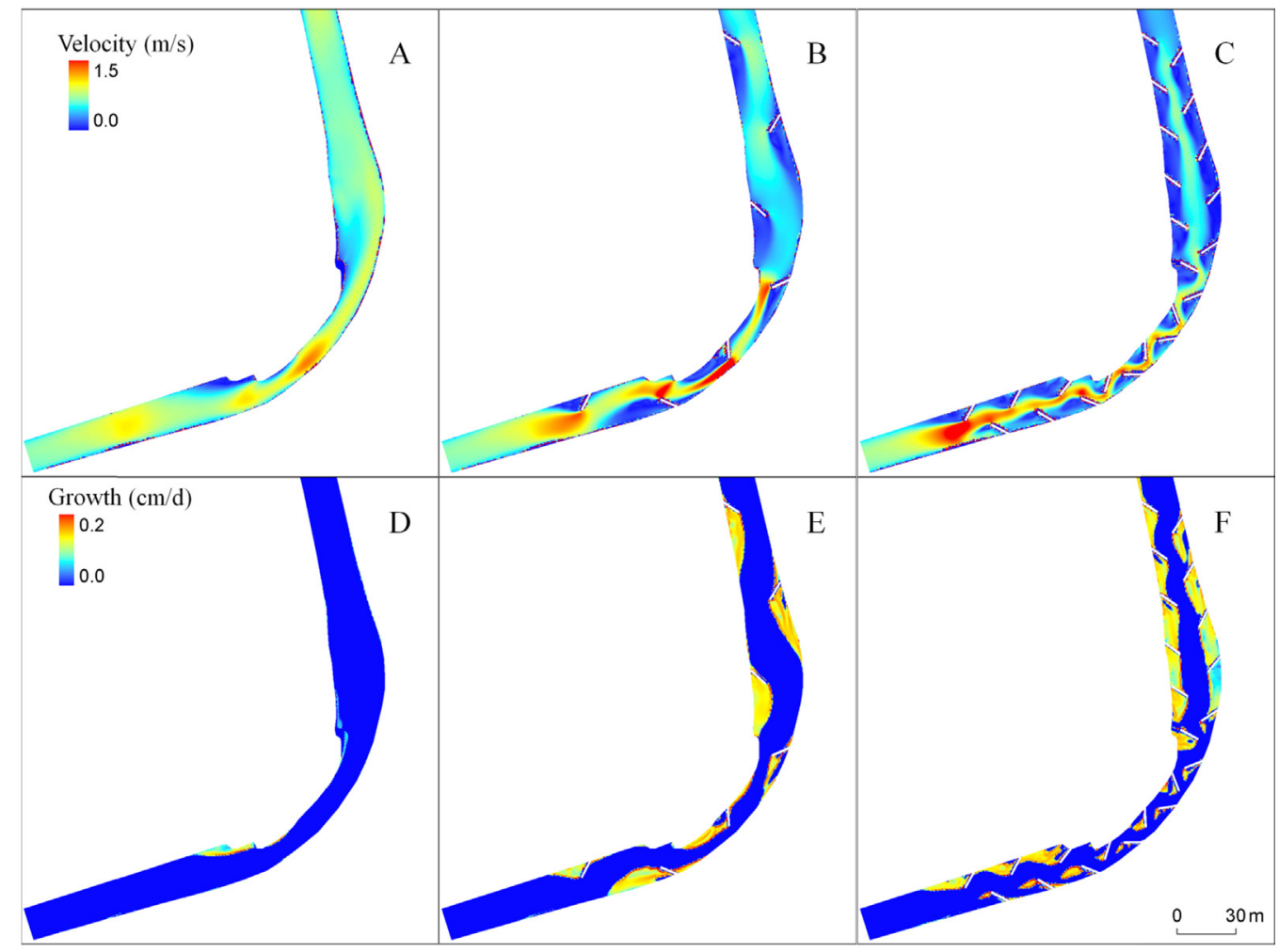

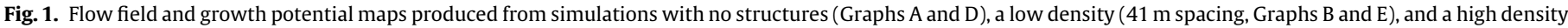
(12.3 $\mathrm{m}$ spacing, Graphs C and F) of $10 \mathrm{~m}$ long structures added.

to obtain a hypothetical unmanaged or lightly managed loading amount of $66 \mathrm{~m}^{2} / 100 \mathrm{~m}$ for a Central Valley river.

\section{Results}

\subsection{Effects of woody debris density}

The simulated addition of woody debris influenced both the flow field and the locations where juvenile Chinook salmon growth was possible (Fig. 1). Simulations of the velocity field without woody structures indicated that only small areas of slow flow existed upstream and downstream of the point bar (Fig. 1A), providing little habitat with positive growth potential (Fig. 1D). Added wood enhanced the velocity gradients near structures, created low-velocity wakes downstream of structures (Fig. 1B and C) and reduced the reach-averaged velocity by $5-19 \%$ over the range of simulated wood loading amounts. As woody debris density increased, the areal extent of potential juvenile salmon growth also increased (Fig. $1 \mathrm{E}$ and $\mathrm{F}$ ). The trend exhibited an asymptote at which the river became saturated with structures and additional wood loading resulted in minimal benefit (at about $45 \mathrm{~m}^{2}$ of structure per $100 \mathrm{~m}$ of river reach for the configuration that we chose; $\left(Y=792 /\left(1+3.3 e^{(-0.09 X)}\right), r^{2}=0.87, p<0.01\right)$; Fig. 2). The limit on the area with positive growth potential arose because increasing LWD loads reduced the cross-sectional area of flow and thus increased the velocity in this zone. Simulation results for $5 \mathrm{~m}$ structures predicted that the amount of habitat with positive growth potential would be on average $8.6 \%$ less than those for similar $10 \mathrm{~m}$ structure loading amounts. The relationship between structure loading and the amount of area capable of producing a viable fish of $10 \mathrm{~cm}$ length by the end of the simulation period was similar to the pattern of zones generating any net growth $\left(\left(Y=769 /\left(1+3.7 e^{(-0.09 X)}\right)\right.\right.$, $r^{2}=0.88, p<0.01$ ); Fig. 2).

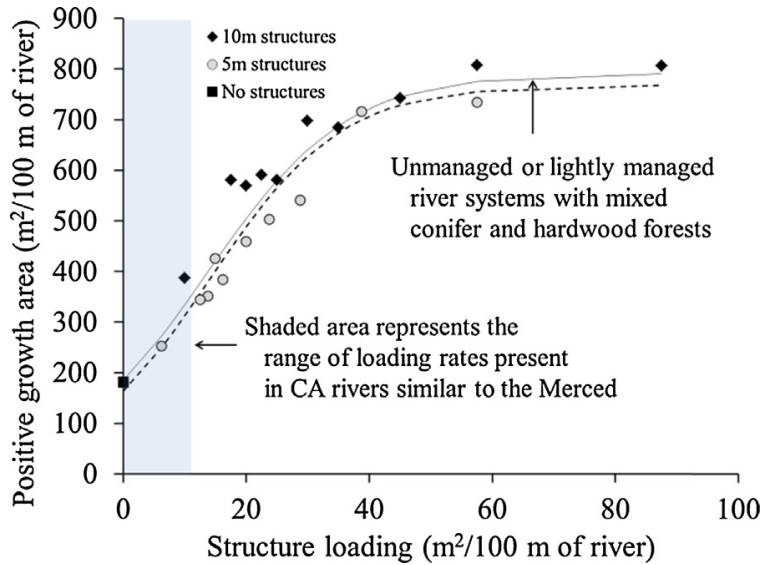

Fig. 2. Relationship between structure loading and the area per $100 \mathrm{~m}$ averaged over the entire channel where juvenile salmon growth (points and solid line) was predicted to occur $\left(Y=792 /\left(1+3.3 e^{(-0.09 X)}\right), r^{2}=0.87, p<0.01\right)$. On average, when comparing similar loading amounts, simulations with $10 \mathrm{~m}$ long structures create $8.6 \%$ more growth area than $5 \mathrm{~m}$ long structure simulations. The predicted amount of area that would produce a viable fish capable of growing to the average outmigration size of $10 \mathrm{~cm}$ is represented by the dotted line $\left(Y=769 /\left(1+3.7 \mathrm{e}^{(-0.09 X)}\right), r^{2}=0.88\right.$, $p<0.01)$. The portions of the curves within the shaded area represent the growth area predicted to be available if the structure loading amount was within the range of woody debris loading amounts measured for 20 California rivers (Albertson et al., 2013) similar to the Merced and the vertical arrow indicates an estimate for unmanaged or lightly managed river systems with conifer and hardwood (Gurnell et al., 2002).

\subsection{Structure placement in curved and straight sections}

The relationship between wood structure loading and areal extent of habitat with the potential to support fish growth differed between curved $\left(Y=535 /\left(1+1.9 e^{(-0.10 X)}\right), r^{2}=0.72, p<0.01\right)$ and straight reaches $\left(\left(Y=1068 /\left(1+3.9 e^{(-0.07 X)}\right), r^{2}=0.87, p<0.01\right)\right.$; 


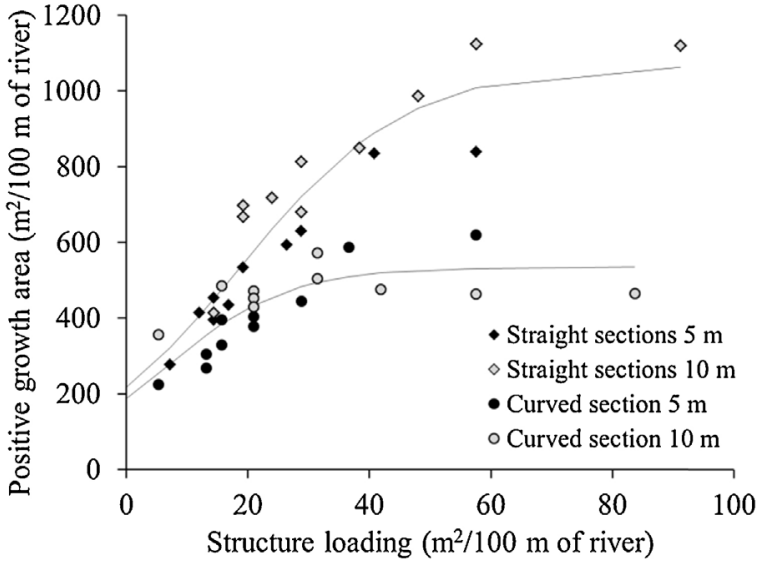

Fig. 3. Relationship between structure loading (both 5 and $10 \mathrm{~m}$ simulations included) and the amount of area where positive juvenile Chinook salmon growth was predicted to occur per $100 \mathrm{~m}$ of curved $\left(Y=535 /\left(1+1.9 e^{(-0.10 X)}\right), r^{2}=0.72\right.$, $p<0.01)$ and straight reaches $\left(Y=1068 /\left(1+3.9 \mathrm{e}^{(-0.07 X)}\right), r^{2}=0.87, p<0.01\right)$.

Fig. 3). Increasing the structure density led to more habitat being available for positive growth in both reaches, but the growtharea response approached a lower asymptote in the curved reach. Structures placed in straight sections resulted in larger areas of potential growth, especially at higher structure loadings (Fig. 3). The projection of LWD into the narrower and deeper curved reaches accelerated flow in the unobstructed portions of the channel, rendering them unfavorable for fish to hold in. With increased wood loading amounts, curved reaches experienced a more pronounced contraction and acceleration of the high-velocity core due to the interactions between structures, which reduced wake lengths (Fig. 1C) and reach-averaged growth potential (Fig. 1F).

\subsection{Flow complexity}

Velocity differential (defined here as the drift velocity, which is the fastest velocity in the cells adjacent to the fish location, minus the velocity at the fish location) had a large influence on determining if and how a location favored juvenile Chinook salmon growth. Simulated LWD provided the habitat complexity that established flow fields with high velocity differentials. The bioenergetic model predicted that locations at the edge of the wake created by individual structures would have the highest growth potential. These locations had high drift velocities outside of the wake toward the center of the river, which were adjacent to low velocity locations in the wake created by the structure (Fig. 4). The addition of wood also opened up larger fractions of the deeper portion of the channel for positive growth, which would otherwise be uninhabitable. In the absence of added wood, the areas where positive growth was possible were limited to the slow velocity $(<0.3 \mathrm{~m} / \mathrm{s})$ zones along the channel margins (Fig. 1A and D).

The effectiveness of a velocity differential in providing growth opportunities was strongest in deeper water (1-1.5 m) and did not appear to have a positive influence on fish growth in the shallow channel margins (depth $<0.25 \mathrm{~m}$ ), despite the low swimming costs associated with this environment (Fig. 5). The food capture area in the bioenergetics model was set as a function of the flow depth, with deeper water providing a larger capture diameter for the fish and thus increasing the feeding opportunities. Conversely, while the slow moving water on the channel margins provides suitable resting habitat, the shallow flow depth and low rate of food delivery nearby limits the growth potential. In deeper water, a fish was both more likely to find a strong velocity gradient, and the feeding potential increased due to the larger capture area in deeper water.

\section{Discussion}

Predicting the effects of wood additions on salmon populations inherently involves substantial difficulties due to local biophysical conditions which make it difficult to isolate the effects of wood from those of other factors (Bisson et al., 2003). Our findings represent a first step toward overcoming these challenges by quantifying the role of large wood on salmon growth potential using an integrated hydrodynamic and bioenergetic modeling framework in a meandering river that currently lacks woody debris. By
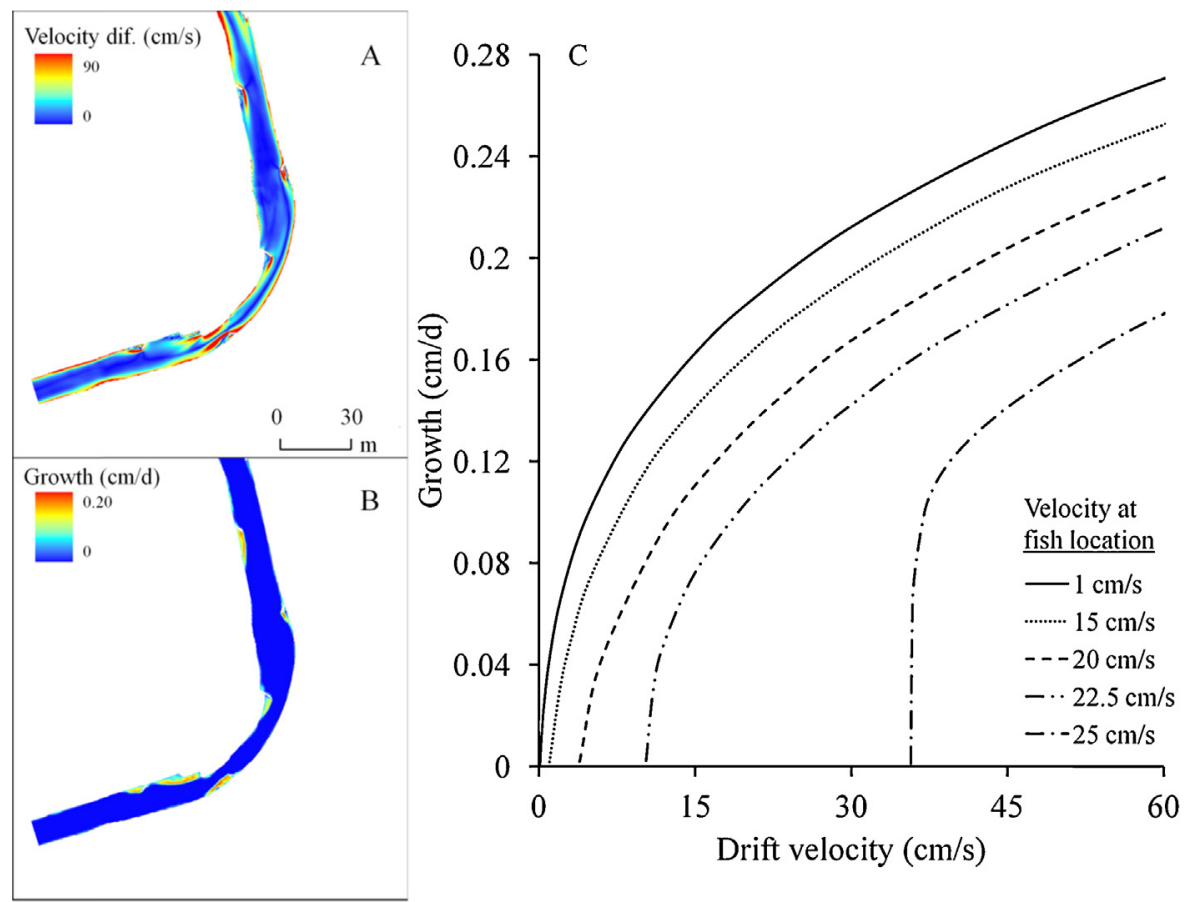

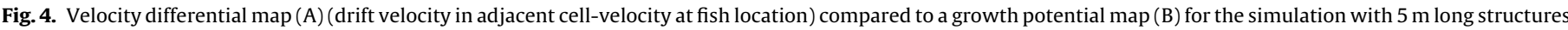
added spaced $62 \mathrm{~m}$ apart. Also provided is $(\mathrm{C})$ the relationship between growth potential, drift velocity, and velocity at any fish location. 


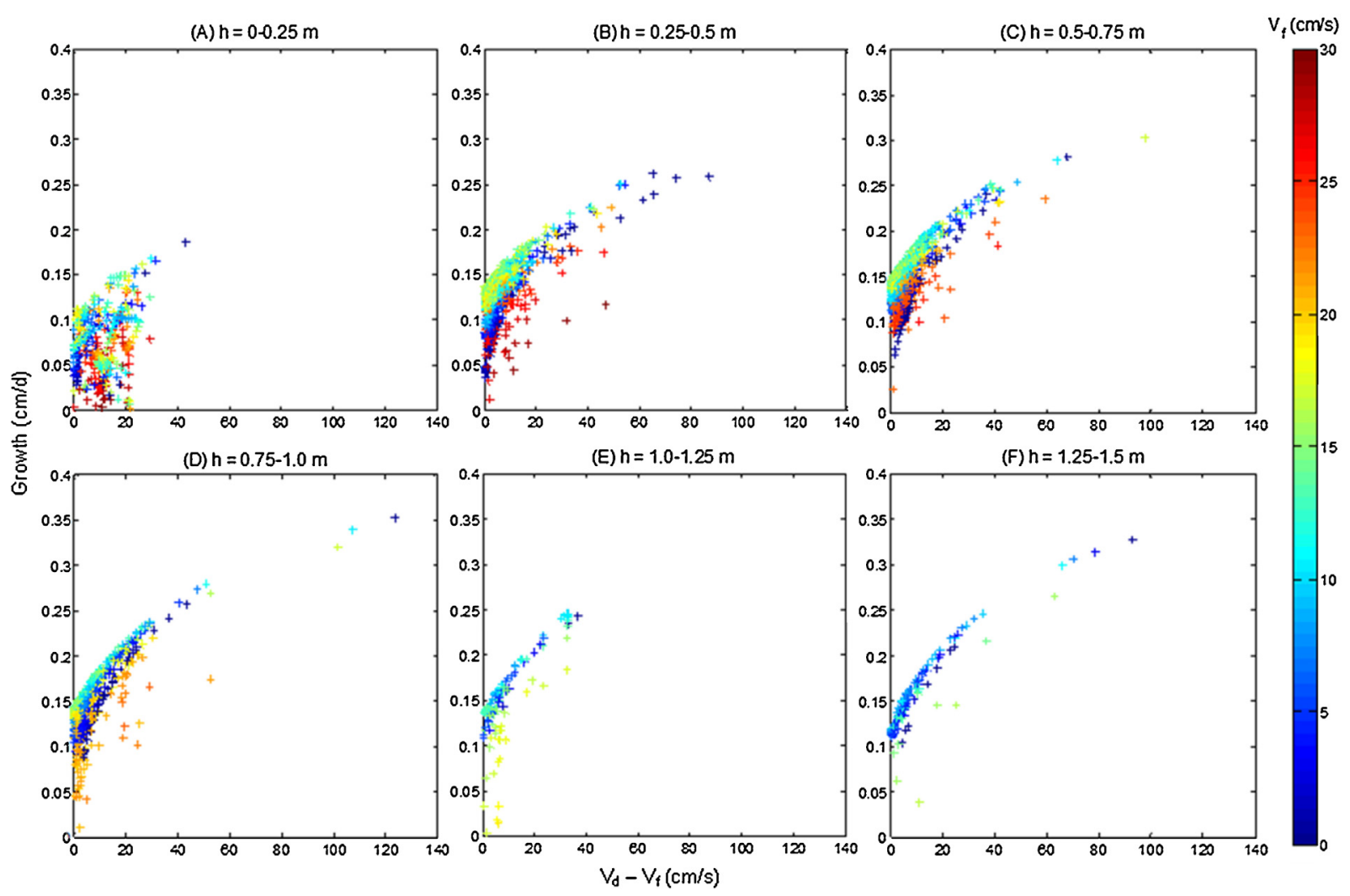

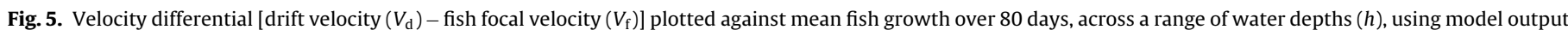
from the low wood density simulation shown in Fig. $1 \mathrm{~B}$ and $\mathrm{E}$ for illustration. Individual data points are colored by the value of $V_{\mathrm{f}}$.

systematically adding constant-sized units of wood to a hydrodynamic model of the channel, we quantified the incremental effect of structure loading on the flow field and thus salmon growth potential. The approach allowed us to map locations with the potential to sustain positive fish growth, to determine which locations were able to produce a fish of viable smoltification size $(10 \mathrm{~cm})$, and to estimate the relationship between LWD loading and the channel area with a potential for supporting positive juvenile salmon growth.

Wood influenced the flow structure and salmon growth potential at both the sub-meter and reach scales. At high LWD loading amounts, the reach-scale average velocity decreased by 5-19\% and the area of habitat supporting growth of juvenile salmon quadrupled. At the micro-habitat scale, wood created both low-velocity wakes behind structures and flow accelerations adjacent to the structures. The combined effect at the scale of individual structures was to intensify velocity gradients and fish growth potential. Previous studies have qualitatively emphasized the importance of velocity gradients for fish, and Fausch (1984) used laboratory experiments to demonstrate that drift-feeding fish grow at faster rates when they can hold position in slow water (to minimize swimming energy expenditures) and feed in adjacent faster water (to maximize available invertebrate drift supply). Subsequent work has extended this finding to field settings using flow-based metrics, such as vorticity, to quantify flow complexity using computed velocity gradients (Crowder and Diplas, 2002). While such metrics can differentiate between flows of varying complexity in gravelbedded or boulder-rich channels, they have not been directly linked to an anticipated biological response to flows of varying complexity. The approach used here provides a direct means of quantifying how flows of different complexity translate into fish growth potential over a range of spatial scales and food supply. The coupled modeling approach also highlights that the benefits of a velocity differential on fish growth are most likely to be realized when combined with a low fish focal velocity (in our case $<0.3 \mathrm{~m} / \mathrm{s}$ ), and sufficient water depth $(>0.25 \mathrm{~m})$, and that these three ingredients (velocity differential, low focal velocity and deep water) need to occur at a small enough $(\sim 1 \mathrm{~m})$ spatial scale for fish to exploit the growth opportunities.

Results from the study could be applied in several ways. One relates to the case of resident fish or juvenile salmon that remain more-or-less local throughout the rearing season until they are driven downstream by increasing temperatures (in the case of the Merced River) or other stimuli. In those cases, the useful metric to extract from the results is the area in which a fish with an initial fork length of $7 \mathrm{~cm}$ could grow to a viable length for successful smoltification in the time available. This is the habitat potential indicated by the dashed curve in Fig. 2. In the case of the MRSHEP reach Chinook, the average fish is approximately $8-10 \mathrm{~cm}$ when it migrates out of the river (Montgomery et al., 2007). Another way of interpreting our results is from the perspective of a juvenile salmon gradually migrating downstream throughout the rearing season exploiting whatever rearing conditions it encounters along its path. Such habitat potential is portrayed in Fig. 1 and in the solid curve of Fig. 2. In the MRSHEP reach, the curves in Fig. 2 are essentially identical, but whether this result is consistent in other systems remains to be seen.

In the model simulations, the presence of a fish in one location does not influence invertebrate drift concentration in other locations and therefore growth rates are independent of intraspecific interactions among salmon. Yet benthic invertebrate populations may be depleted by drift-feeding fishes (Meissner and Muotka, 2006) and salmonids typically exhibit density-dependent growth rates caused by antagonistic behavior (Grant and Imre, 2005). Thus the form of the relationships presented in this study may be influenced by salmon density-dependent effects if prey supply rates or intraspecific interactions affect the modeled dynamics before asymptotic growth potentials are attained. However, in the 
Merced River and many rivers lacking extensive habitat complexity, density-dependent effects, especially those related to food supply, are likely to prove insignificant until salmonid populations increase substantially from contemporary sizes. In the case of our modeled system, doubling the modeled density of salmon from 0.78 individuals per $\mathrm{m}^{2}$ (i.e., one fish spaced every $0.5 \mathrm{~m}$ ) would decrease final growth rates by only $\sim 3 \%$ based on the empirical relationship $\left(Y=5.2 X^{-0.045}\right)$ between fish density and size based on field sampling of juvenile salmonids by Grant and Imre (2005). Recent seine surveys of the study reach detected a mean salmon parr density of $<0.01$ per $\mathrm{m}^{2}$ and a maximum of 0.11 per $\mathrm{m}^{2}$ (Utz et al., 2012), thus current population densities would need to increase substantially before density dependent effects could be expected. Furthermore, LWD additions should elevate macroinvertebrate abundance in rivers (Benke et al., 1984; Hrodey et al., 2008), thereby buffering the depletion of prey resources if salmon populations increase.

By using the depth-averaged velocity at each point we ignore low-velocity zones near the river bed that could support fish growth. Our field measurements and the flow computations with FaSTMECH for a discharge of $6.4 \mathrm{~m}^{3} / \mathrm{s}$ indicate that over most of the straight reach where the mean flow depth is $0.65 \mathrm{~m}$ there is a $0.15 \mathrm{~m}$ thick near-bed zone in which the velocity ranges from zero to $75 \%$ of the vertically averaged flow speed. This layer constitutes most of the flow depth within $3 \mathrm{~m}$ of the channel margins. In addition to the role of this zone and the surface intra-gravel zone as habitat for the alevin life stage, it could also provide habitat for the juvenile stage that we have modeled, and thus our model might underestimate the full habitat potential of the reach. We have also modeled only the case where the woody structure is impermeable, such as a solid tree trunk. The hydrodynamic model could be utilized to compute flow fields around and through permeable barriers produced by large, compound log jams, but a three-dimensional flow model would be required to calculate velocity variations in the vertical that may be associated with these larger features.

Our results indicated that a sufficient length between structures was required to produce downstream zones of low velocity that were predicted to provide positive growth. When the structure spacing was increased (panel $\mathrm{C}$ and $\mathrm{F}$ of Fig. 1), minimal benefit was observed. If the structures were placed randomly, we would expect to see positive growth conditions when the spacing allowed (i.e. the wakes were not disrupted) but minimal benefit if the structures were spaced closely. The exact spacing that would provide adequate wakes or disrupt them would depend on the channel width and curvature of a particular river.

The simulations relate to a particular channel size and gradient, water temperature, and invertebrate food supply, but they could be repeated for different combinations of habitat characteristics in other river channels and seasonally inundated floodplains (Jeffres et al., 2008). Light detection and ranging (LiDAR) techniques have become increasingly popular tools for mapping channel and floodplain bathymetry (McKean et al., 2008) and wood (Kasprak et al., 2012) up to catchment scales. Our intention here is to illustrate the general principle of coupling hydrodynamic and bioenergetic models to estimate habitat potential related to varying degrees of wood loading, and thus we have not addressed the other obvious issue of parameter estimation, particularly for the bioenergetic model. We simply chose a parameter set regarded as representative for the species involved from a widely employed source.

The form of a river channel depends on the populations of flows, sediment supplies, and LWD supplied to the river (Collins et al., 2012; Gurnell, 2012). River management has tended to focus on altering flow and sediment supply in attempts to reactivate geomorphic processes that shape aquatic habitats, based on existing conceptual models of alluvial river behavior (Trush et al., 2000). While flow and sediment transport processes can produce a range of habitat conditions, when acting alone they tend to create smooth channel forms that lack strong velocity gradients required by aquatic organisms (Harrison et al., 2011). In this study, the simulated addition of large wood created a 4-fold increase in the extent of juvenile salmon habitat, in comparison to the existing habitat that has been shaped by a decade of flow and sediment transport since construction. LWD or other non-granular structural elements constitute a critical third factor creating bioenergetically favorable conditions for fish growth. Coupled models of the kind we have implemented allow the quantitative examination of this non-alluvial component of river habitat formation.

Due to the widespread nature of wood depletion in rivers, wood management has become an important tool in river restoration. Yet, despite the widely accepted importance of wood in creating more complex habitats, the nature of its biological influence has been difficult to quantify (Abbe and Brooks, 2011). The simulations presented here estimate quantitatively the growth potential benefits for drift feeding Chinook salmon that might be gained from wood additions. Our findings also suggest that a wood loading value exists at which additional structure would result in limited additional usable rearing habitat, at least for a particular configuration of wood installation. The 20 California rivers measured by Albertson et al. (2013) possessed LWD loading amounts far below those reported in unmanaged or lightly managed river systems (Gurnell et al., 2002). Based on the results of our study and others (Albertson et al., 2013; Gurnell et al., 2002; Sedell and Froggatt, 1984; Senter and Pasternack, 2011), most of the managed rivers where wood loading amounts have been reported are currently far below the saturation point predicted by our model.

The modeling approach used in our study could reduce the uncertainty in restoration projects where adding structural complexity has been identified as a restoration priority to maintain a sustainable river ecosystem while simultaneously maintaining other values such as boat access and flood conveyance. The finding from our modeling efforts that a saturation point exists between wood loading and fish growth provides a hypothesis that could be tested with high-resolution field experiments involving wood additions and monitoring of fish distributions, growth and food intake. The integrated modeling approach also presents a basis for developing theories linking in-channel ecological conditions with three major watershed-supplied influences: flows, sediment supplies, and woody debris (Benda et al., 2003; Collins et al., 2012; Gurnell, 2012). Although we have implemented the original bioenergetic model with published parameter values, the general form of the relationship between wood loading and extent of juvenile rearing habitat, presented in Figs. 2 and 3, could be applied in other river systems with adjusted parameter values reflecting local ecological differences. The integrated modeling approach we used in this study is best described as drift foraging theory translated into numerical bioenergetics which is harnessed to hydrodynamic modeling in order to predict growth potential. This approach allows assessment of the ecological benefits of alternative channel morphologies or wood loading amounts. This is an approach that is transferable to any river or flow because it is process based.

\section{Acknowledgments}

This project was funded by the Delta Stewardship Council, Delta Science Program (grant no. U-05-SC-058). The suggestion to analyze the potential for improving habitat by adding structure to a simplified channel was first made to us by Fred P. Jurick of the California Department of Fish and Game. Kevin Faulkenberry and David Encinas of the California Department of Water Resources assisted with hydraulic information about the MRSHEP channel reach. We are grateful to Bruce Kendall, Steve Lindley, John Melack, and John Sabo for providing comments that improved this manuscript. 


\section{Appendix A. Supplementary data}

Supplementary data associated with this article can be found, in the online version, at http://dx.doi.org/10.1016/j.ecolmodel. 2014.04.015.

\section{References}

Abbe, T., Brooks, A., 2011. Geomorphic, Engineering, and Ecological Considerations when Using Wood in River Restoration. In: Simon, A., Bennett, S.J., Castro, J.M. (Eds.), Stream Restoration in Dynamic Fluvial Systems. American Geophysical Union, Washington, D.C., pp. 419-451.

Albertson, L.K., Koenig, L.E., Lewis, B.L., Zeug, S.C., Harrison, L.R., Cardinale, B.J., 2013. How does restored habitat for Chinook salmon (Oncorhynchus Tshawytscha) in the Merced River in California compare with other Chinook streams? River Res. Appl. 29, 469-482.

Barton, G.J., McDonald, R.R., Nelson, J.M., Dinehart, R.L., 2005. Simulation of flow and sediment mobility using a multidimensional flow model for the white sturgeon critical habitat reach. In: Kootenai River near Bonners Ferry. U.S. Geol. Surv. Sci. Invest. Rep. 2005-5230.

Beamish, F.W.H., 1974. Apparent specific dynamic action of largemouth bass, Micropterus salmoides. J. Fish. Res. Board Can. 31, 1763-1769.

Beechie, T.J., Sibley, T.H., 1997. Relationships between channel characteristics, woody debris, and fish habitat in northwestern Washington streams. Trans. Am. Fish. Soc. 126, 217-229.

Benda, L., Miller, D., Sias, J., Martin, D., Bilby, R., Veldhuisen, C., et al., 2003. Wood recruitment processes and wood budgeting. In: Gregory, S.V., Boyer, K.L., Gurnell, A.M. (Eds.), The Ecology and Management of Wood in World Rivers, Symposium 37. American Fisheries Society, Bethesda, MD, pp. 49-73.

Benke, A.C., Arsdall Jr., T.C.V., Gillespie, D.M., Parrish, F.K., 1984. Invertebrate productivity in a subtropical blackwater river: the importance of habitat and life history. Ecol. Monograph. 54, 25-63.

Bisson, P.A., Wondzell, S.M., Reeves, G.H., Gregory, S.V., 2003. Trends in using wood to restore aquatic habitats and fish communities in western North American rivers. In: Gregory, S.V., Boyer, K., Gurnell, A.M. (Eds.), The Ecology and Management of Wood in World Rivers, vol. Symposium 37. American Fisheries Society, Bethesda, MD, pp. 391-406.

Bocchiola, D., 2011. Hydraulic characteristics and habitat suitability in presence of woody debris: a flume experiment. Adv. Water Resour. 34, 1304-1319.

Booker, D.J., Dunbar, M.J., Ibbotson, A., 2004. Predicting juvenile salmonid driftfeeding habitat quality using a three-dimensional hydraulic-bioenergetic model. Ecol. Model. 177, 157-177.

Cederholm, C.J., Bilby, R.E., Bisson, P.A., Bumstead, T.W., Fransen, B.R., Scarlett, W.J., et al., 1997. Response of juvenile coho salmon and steelhead to placement of large woody debris in a coastal Washington stream. N. Am. J. Fish. Manage. 17, 947-963.

Collins, B.D., Montgomery, D.R., Haas, A.D., 2002. Historical changes in the distribution and functions of large wood in Puget lowland rivers. Can. J. Fish. Aquat. Sci. 59, 66-76.

Collins, B.D., Montgomery, D.R., Fetherston, K.L., Abbe, T.B., 2012. The floodplain large-wood cycle hypothesis: a mechanism for the physical and biotic structuring of temperate forested alluvial valleys in the North Pacific coastal ecoregion. Geomorphology 139/140, 460-470.

Crowder, D.W., Diplas, P., 2000. Using two-dimensional hydrodynamic models at scales of ecological importance. J. Hydrol. 230, 172-191.

Crowder, D.W., Diplas, P., 2002. Vorticity and circulation: spatial metrics for evaluating flow complexity in stream habitats. Can. J. Fish. Aquat. Sci. 59, 633-645.

Everett, R.A., Ruiz, G.M., 1993. Coarse woody debris as a refuge from predation in aquatic communities. Oecologia 93, 475-486.

Fausch, K.D., 1984. Profitable stream positions for salmonids: relating specific growth rate to net energy gain. Can. J. Zool. 62, 441-451.

Floyd, T.A., MacInnis, C., Taylor, B.R., 2009. Effects of artificial woody structures on Atlantic salmon habitat and populations in a Nova Scotia stream. River Res. Appl. $25,272-282$

Grant, J.W.A., Imre, I., 2005. Patterns of density-dependent growth in juvenile stream-dwelling salmonids. J. Fish Biol. 67, 100-110.

Grothendieck, G., 2010. Non-linear regression with brute force. R package version 0.1-3, http://CRAN.R-project.org/package=nls2

Gurnell, A., 2012. Fluvial geomorphology: wood and river landscapes. Nat. Geosci. 5, 93-94.

Gurnell, A.M., PiéGay, H., Swanson, F.J., Gregory, S.V., 2002. Large wood and fluvial processes. Freshw. Biol. 47, 601-619.

Gurnell, A., Tockner, K., Edwards, P., Petts, G., 2005. Effects of deposited wood on biocomplexity of river corridors. Front. Ecol. Environ. 3, 377-382.

Hanson, P.C., Johnson, T.B., Schindler, D.E., Kitchell, J.F., 1997. Fish Bioenergetics 3. 0 . Center for Limnology, University of Wisconsin, Madison.

Harmon, M.E., Franklin, J.F., Swanson, F.J., Sollins, P., Gregory, S.V., Lattin, J.D., et al., 1986. Ecology of coarse woody debris in temperate ecosystems. Adv. Ecol. Res. $15,133-302$

Harrison, L.R., Keller, E.A., 2007. Modeling forced pool-riffle hydraulics in a boulderbed stream, southern California. Geomorphology 83, 232-248.

Harrison, L.R., Legleiter, C.J., Wydzga, M.A., Dunne, T., 2011. Channel dynamics and habitat development in a meandering, gravel bed river. Water Resour. Res. 47, W04513.
Hayes, J.W., Stark, J.D., Shearer, K.A., 2000. Development and test of a whole-lifetime foraging and bioenergetics growth model for drift-feeding brown trout. Trans. Am. Fish. Soc. 129, 315-332.

Hayes, J.W., Hughes, N.F., Kelly, L.H., 2007. Process-based modelling of invertebrate drift transport, net energy intake and reach carrying capacity for drift-feeding salmonids. Ecol. Model. 207, 171-188.

Hill, J., Grossman, G.D., 1993. An energetic model of microhabitat use for rainbow trout and rosyside dace. Ecology 74, 685-698.

Hrodey, P., Kalb, B., Sutton, T., 2008. Macroinvertebrate community response to large-woody debris additions in small warmwater streams. Hydrobiologia 605, 193-207.

Hughes, N.F., Dill, L.M., 1990. Position choice by drift-feeding salmonids: model and test for arctic grayling (Thymallus arcticus) in subarctic mountain streams, interior Alaska. Can. J. Fish. Aquat. Sci. 47, 2039-2048.

Jeffres, C.A., Opperman, J.J., Moyle, P.B., 2008. Ephemeral floodplain habitats provide best growth conditions for juvenile Chinook salmon in a California river. Environ. Biol. Fish. 83, 449-458.

Kasprak, A., Magilligan, F.J., Nislow, K.H., Snyder, N.P., 2012. A LiDAR-derived evaluation of watershed-scale large woody debris sources and recruitment mechanisms: Coastal Maine, USA. River Res. Appl. 28, 1462-1476.

Keller, E.A., Swanson, F.J., 1979. Effects of large organic material on channel form and fluvial processes. Earth Surf. Proc. 4, 361-380.

Koehler, M.E., Fresh, K.L., Beauchamp, D.A., Cordell, J.R., Simenstad, C.A., Seiler, D.E., 2006. Diet and bioenergetics of lake-rearing juvenile Chinook salmon in Lake Washington. Trans. Am. Fish. Soc. 135, 1580-1591.

Legleiter, C.J., Harrison, L.R., Dunne, T., 2011. Effect of point bar development on the local force balance governing flow in a simple, meandering gravel bed river. J. Geophys. Res. 116, F01005.

Lisle, T.E., Nelson, J.M., Pitlick, J., Madej, M.A., Barkett, B.L., 2000. Variability of bed mobility in natural, gravel-bed channels and adjustments to sediment load at local and reach scales. Water Resour. Res. 36, 3743-3755.

Madenjian, C.P., O'Connor, D.V., Chernyak, S.M., Rediske, R.R., O'Keefe, J.P., 2004. Evaluation of a Chinook salmon (Oncorhynchus tshawytscha) bioenergetics model. Can. J. Fish. Aquat. Sci. 61, 627-635.

Marshall, J.A., DeVries, P., Milner, N., 2008. Spawning habitat remediation as part of national and regional scale programs to recover declining salmon populations. In: Sear, D., DeVries, P. (Eds.), Salmonid Spawning Habitat in Rivers: Physical Controls, Biological Responses and Approaches to Remediation. American Fisheries Society, Bethesda, MD, pp. 275-300.

McKean, J.A., Isaak, D.J., Wright, C.W., 2008. Geomorphic controls on salmon nesting patterns described by a new, narrow-beam terrestrial-aquatic lidar. Front. Ecol. Environ. 6, 125-130.

Meissner, K., Muotka, T., 2006. The role of trout in stream food webs: integrating evidence from field surveys and experiments. J. Anim. Ecol. 75, 421-433.

Montgomery, J., Gray, A., Watry, C.B., Pyper, B., 2007. Using Rotary Screw Traps to Determine Juvenile Chinook Salmon Out-migration Abundance, Size and Timing in the Lower Merced River, California. U.S. Fish and Wildlife Service, Anadromous Fish Restoration Program, Lodi, CA.

Nelson, J.M., Bennett, J.P., Wiele, S.M., 2003. Flow and sediment transport modeling. In: Kondolf, G.M., PiÊGay, H. (Eds.), Tools in Fluvial Geomorphology. John Wiley, Chichester, UK, pp. 539-576.

Noss, R.F., La Roe III, E.T., Scott, J.M., 1995. Endangered Ecosystems of the United States: Preliminary Assessment of Loss and Degradation. U.S. Department of the Interior, National Biological Service, Washington, DC, USA.

Pasternack, G.B., Wang, C.L., Merz, J.E., 2004. Application of a 2D hydrodynamic model to design of reach-scale spawning gravel replenishment on the Mokelumne River, California. River Res. Appl. 20, 205-225.

Pellachini, C., 2011. Modeling fine sediment transport over an immobile gravel bed. Dissertation. Department of Civil Environmental and Mechanical Engineering. University of Trento, Italy.

R Core Team, 2012. R: A Language and Environment for Statistical Computing. R Foundation for Statistical Computing, Vienna, Austria, http://www.R-project.org

Railsback, S.F., Gard, M., Harvey, B.C., White, J.L., Zimmerman, J.K.H., 2013. Contrast of degraded and restored stream habitat using an individual-based salmon model. N. Am. J. Fish. Manage. 33, 384-399.

Roni, P., Quinn, T.P., 2001. Density and size of juvenile salmonids in response to placement of large woody debris in western Oregon and Washington streams. Can. J. Fish. Aquat. Sci. 58, 282-292.

Rosenfeld, J.S., Taylor, J., 2009. Prey abundance, channel structure and the allometry of growth rate potential for juvenile trout. Fish. Manage. Ecol. 16, 202-218.

Sada, D.W., Vinyard, G.L., 2002. Great basin aquatic systems history. In: Hershler, R., Madsen, D., Currey, D. (Eds.), Smithsonian Contributions to the Earth Sciences. Smithsonian Institute, Washington, DC, pp. 277-293.

Sedell, J.R., Froggatt, J.L., 1984. Importance of streamside forests to large rivers: the isolation of the Willamette River, Oregon, U.S.A., from its floodplain by snagging and streamside forest removal. In: Verhandlungen der Internationale Vereinigung fur Theoretische und Angewandte Limnologie 22, pp. 1828-1834.

Sedell, J.R., Everest, F.H., Swanson, F.J., 1982. Fish habitat and streamside management: past and present. In: Proceedings of the Society of American Foresters Annual Meeting, Society of American Foresters, Bethesda, MD, 27-30 September, 1981, pp. 244-255.

Senter, A.E., Pasternack, G.B., 2011. Large wood aids spawning Chinook salmon (Oncorhynchus tshawytscha) in marginal habitat on a regulated river in California. River Res. Appl. 27, 550-565. 
Shields, F.D., Knight, S.S., Morin, N., Blank, J., 2003. Response of fishes and aquatic habitats to sand-bed stream restoration using large woody debris. Hydrobiologia 494, 251-257.

Slaney, T.L., Hyatt, K.D., Northcote, T.G., Fielden, R.J., 1996. Status of anadromous salmon and trout in British Columbia and Yukon. Fisheries 21, 20-35.

Sommer, T.R., Nobriga, M.L., Harrell, W.C., Batham, W., Kimmerer, W.J., 2001. Floodplain rearing of juvenile Chinook salmon: evidence of enhanced growth and survival. Can. J. Fish. Aquat. Sci. 58, 325-333.

Stella, J., Battles, J., Orr, B., McBride, J., 2006. Synchrony of seed dispersal, hydrology and local climate in a semi-arid river reach in California. Ecosystems 9, 1200-1214.
Triska, F.J., 1984. Role of wood debris in modifying channel geomorphology and riparian areas of a large lowland river under pristine conditions: a historical case study. In: Verhandlungen der Internationale Vereinigung fur Theoretische und Angewandte Limnologie 22, pp. 1876-1892.

Trush, W.J., McBain, S.M., Leopold, L.B., 2000. Attributes of an alluvial river and their relation to water policy and management. Proc. Natl. Acad. Sci. U. S. A 97, 11858-11863.

Utz, R.M., Zeug, S.C., Cardinale, B.J., 2012. Juvenile Chinook salmon, Oncorhynchus tshawytscha, growth and diet in riverine habitat engineered to improve conditions for spawning. Fish. Manage. Ecol. 19, 375-388.

Wheaton, J.M., Pasternack, G.B., Merz, J.E., 2004. Spawning habitat rehabilitation-I, conceptual approach and methods. Int. J. River Basin Manage. 2, 3-20. 